\title{
Cultivation of Agaricus blazei on Pleurotus spp. Spent Substrate
}

\author{
Regina Maria Miranda Gern ${ }^{1 *}$, Nelson Libardi Junior ${ }^{2}$, Gabriela Nunes Patrício ${ }^{3}$, \\ Elisabeth Wisbeck ${ }^{2}$, Mariane Bonatti Chaves ${ }^{2}$ and Sandra Aparecida Furlan ${ }^{2}$ \\ ${ }^{1}$ Departamento de Ciências Biológicas; Universidade da Região de Joinville; C. P.: 246; Campus Universitário s/n; \\ 89201-972; Joinville - SC - Brasil. ${ }^{2}$ Departamento de Engenharia Ambiental; Universidade da Região de Joinville; \\ ${ }^{3}$ Departamento de Química Industrial; Universidade da Região de Joinville; Joinville - SC - Brasil
}

\begin{abstract}
The aim of this work was the use of Pleurotus ostreatus and Pleurotus sajor-caju for the previous lignocellulolytic decomposition of banana tree leaf straw and the further use of the degraded straw as substrate for the culture of Agaricus blazei. For optimising the production of A. blazei in terms of yield (Y\%) and biological efficiency (BE\%), adjustments to the composition of the substrate were evaluated in a $2^{5}$ experimental design. The following components were tested in relation to \% of substrate dry mass: urea (1 and 10\%), rice bran (10 or 20\%) or ammonium sulphate (0 or 10\%), inoculum (10 or 20\%) and the casing material (subsoil or burned rice husks). The best results $(79.71 \mathrm{Y \%}$ and $6.73 \mathrm{BE} \%)$ were found when the substrate containing $10 \%$ of rice bran, without ammonium sulphate, inoculated with $20 \%$ and covered with subsoil was used.
\end{abstract}

Key words: Agro-industrial Wastes, Basidiomycetes, Edible Mushrooms, Fungi, Lignocellulosic Degradation, Solid State Fermentation

\section{INTRODUCTION}

The culture of edible and medicinal mushrooms has become an attractive economic alternative over the past few years, mainly due to the increase in its demand (Chang 1996) and market value. The characteristic of this culture to add value to the agricultural and agro-industrial wastes (GundeCimerman 1999) requiring a great amount of human resource contributes to a distribution of income and capitalization of the small rural producers. Commercial culture of edible mushrooms can make use of a large range of agroindustrial wastes (sawdust, paper, cereal straw, maize, sugar-cane bagasse, coffee pulp, banana leaves, agave wastes, soy pulp etc) (Patrabansh and Madan 1997; Obodai et al. 2003; Hernández et al. 2003; Bonatti et al. 2004; Salmones et al. 2005). The choice of the substrate generally is determined by the regional availability of the material to be used. The culture of banana is significant in some states of Brazil, generating the straw of the banana tree leaves as waste, which is a good substrate for $P$. ostreatus growth (Silveira et al. 2006; Bonatti et al. 2004). On the other hand, Agaricus blazei is a secondary decompositor and cannot grow directly on cellulose and lignin present in the straw, requiring a previous

*Author for correspondence: rgern@ univille.br 
degradation of the substrate through a composting process (Oei 1996). Analyses of the banana leaf straw after its use in the culture of $P$. ostreatus (spent substrate) has shown that the degradation of this lignocellulosic material promoted by the action of lignocellulolytic enzymes excreted by Pleurotus makes this spent substrate desirable for diverse uses, such as animal feed, mulch in agriculture and substrate for growing fungi (Zadrazil and Puniya 1995; Kanotra and Mathur 1994; Royse 1992; Silva et al. 2002).

The aim of this work was to evaluate the possibility of using the $P$. ostreatus and $P$. sajorcaju spent substrate to grow Agaricus blazei. According with Eira and Nascimento (2007) Brazil is one of the main producers of A. blazei, recently named as A. brasiliensis (Murrill) S. Wasser and popularly denominated "Royal-sunAgaricus" in Brazil and Himematsutake in Japan. The growth of this mushroom started in Brazil in the 1990s, raising great interest in the Asian and North American markets due to its medicinal properties, especially its anti-oncogenic activity that adds a great value to this species.

Adjustments in the composition of the spent substrate of $P$. ostreatus, such as the source and the concentration of the organic and inorganic nitrogen, the inoculum rate and the casing material were evaluated in this work in order to enhance the production of A. blazei in terms of yield and biological efficiency.

\section{MATERIALS AND METHODS}

\section{Microorganisms}

Pleurotus ostreatus DSM 1833, Pleurotus sajorcaju CCB 019 and A. blazei (a commercial grain spawn supplied by Fazenda Guirra - São PauloBrazil), were used in this work.

\section{Experimental design}

Table 1 shows the $2^{5}$ experimental design that was performed to evaluate the influence of five factors on biological efficiency (BE\%) and yield (Y\%) of A. blazei: the inoculum rate $(10 \%$ at the minimum level (-), 20\% at the maximum level (+) and $15 \%$ at central point), the concentration of inorganic nitrogen $(0 \%$ of ammonium sulphate at the minimum level (-), $10 \%$ at the maximum level (+) and $5 \%$ at central point), the source of organic nitrogen (rice bran at the minimum level, urea at the maximum level and the absence of organic nitrogen at the central point), the concentration of organic nitrogen $(10 \%$ of rice bran or $1 \%$ of urea at the minimum level, $20 \%$ of rice bran or $10 \%$ of urea at the maximum level and $0 \%$ of both at central point) and the casing material (burned rice husk at the minimum level, subsoil at the maximum level and a mix of $50 \%$ of both at central point). Percentages were calculated on substrate dry mass basis. The experiments were carried out in eight replicates and three values were chosen using the Dixon statistical treatment (Rorabacher 1991) for calculating the average value. The experimental design was analysed by the statistical program STATISTICA®6.0.

\section{Spent substrate production}

$P$. ostreatus or P. sajor-caju were grown in banana leaf straw according to the method described by Bonatti et al. (2004). After the second flush, the spent straw was dried in an oven at $90^{\circ} \mathrm{C}$ for $24 \mathrm{~h}$ and stored at room temperature.

\section{A. blazei production}

The spent substrate was immersed in water for $12 \mathrm{~h}$ and, after that the excess water was removed. The wet straw was supplemented with $\mathrm{CaCO}_{3}$ (for adjusting the $\mathrm{pH}$ close to neutral) and with the nitrogen source (urea, rice bran or ammonium sulphate). One hundred grams (dry mass basis) of supplemented straw were conditioned in polyetilen bags and autoclaved at $1 \mathrm{~atm}$ for $1 \mathrm{~h}$. The sterilized substrate was inoculated with 10 or $20 \%$ of the $A$. blazei commercial grain spawn in $10 \times 20 \times 15 \mathrm{~cm}$ flasks and incubated in a room with controlled temperature $\left(25^{\circ} \mathrm{C}\right)$ and relative humidity (80$90 \%$ ). After a period of approximately 25 days, when the substrate was completely colonized with the fungal mycelium, the bags were opened and covered with about $8 \mathrm{~cm}$ of the casing material (subsoil or burned rice husk). About 40 days after casing, pinning was observed. The harvest was carried out when the mushroom was almost open. The fruiting bodies were weighed before and after $24 \mathrm{~h}$ of dehydration at $40^{\circ} \mathrm{C}$. The experiments were evaluated in terms of yield $(\mathrm{Y} \%=$ mushroom fresh weight*100/substrate dry weight) and biological efficiency $(\mathrm{BE} \%=$ mushroom dry weight*100/substrate dry weight). 
Table $1-2^{5}$ Experimental design.

\begin{tabular}{lccc}
\hline \multirow{2}{*}{ Factors } & & Level & \\
\cline { 2 - 4 } & Minimum level $(-)$ & Central Point & Maximum level (+) \\
\hline Inoculum rate & $10 \%(\mathrm{dm})$ & $15 \%(\mathrm{dm})$ & $20 \%(\mathrm{dm})$ \\
Ammonium sulphate & $0 \%(\mathrm{dm})$ & $5 \%(\mathrm{dm})$ & $10 \%(\mathrm{dm})$ \\
Source of organic nitrogen & Rice bran & - & Urea \\
Organic nitrogen & $10 \%(\mathrm{dm})$ rice bran and 1\% & - & $20 \%(\mathrm{dm})$ rice bran \\
concentration & $(\mathrm{dm})$ urea & Burned rice husk/ Subsoil & and $10 \%(\mathrm{dm})$ urea \\
Casing material & Burned rice husk & & Subsoil \\
\hline
\end{tabular}

$\mathrm{dm}=$ substrate dry mass.

Table 2 - Biological efficiency (BE\%) and yield (Y\%) for A blazei grown on 33 different conditions involving substrate formulation, inoculum concentration and casing material (average of triplicates).

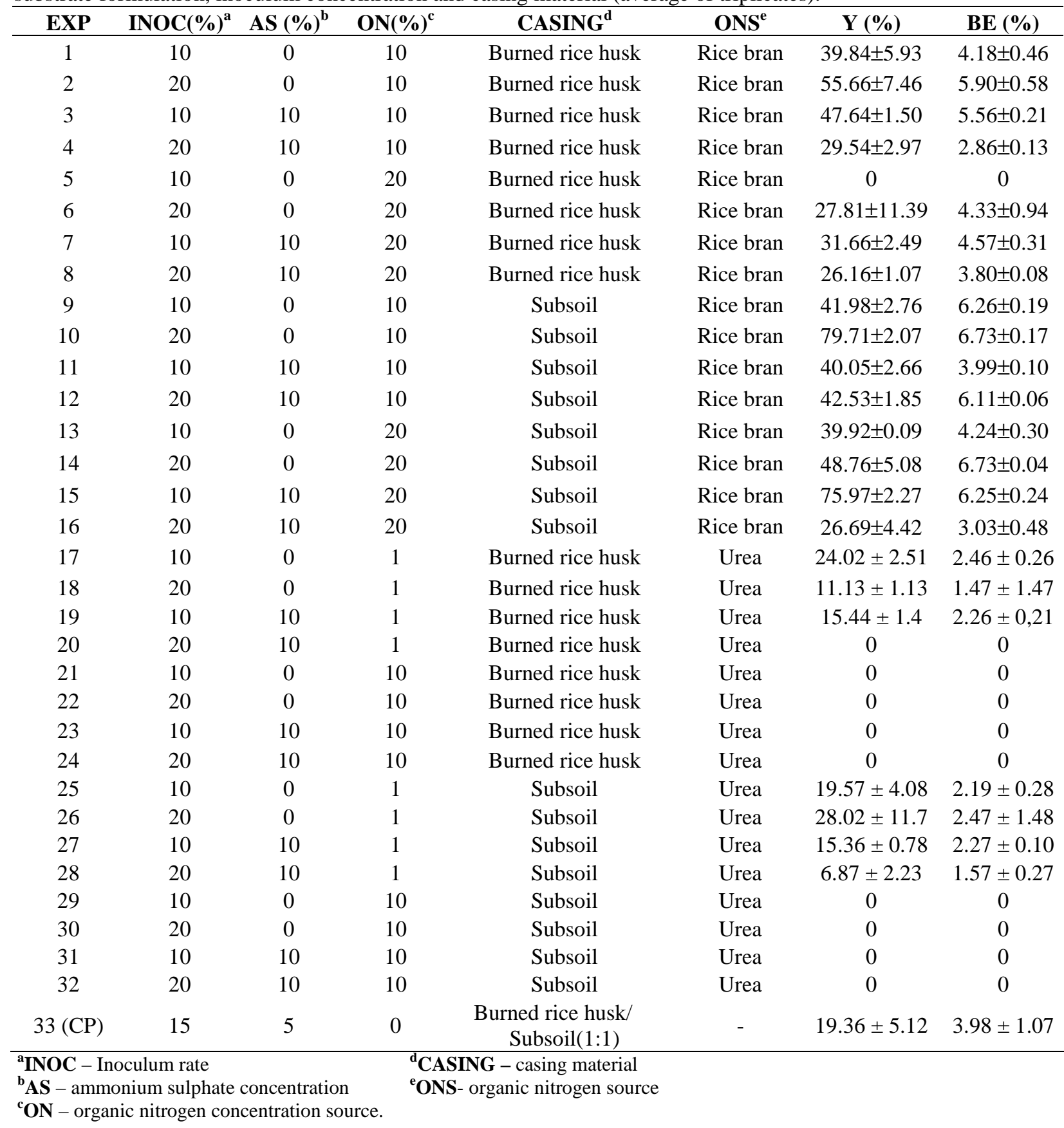




\section{RESULTS AND DISCUSSIONS}

Table 2 shows the results obtained for the biological efficiency and yield using different conditions performed in accordance with the experimental design for A. blazei culture. Among the conditions evaluated, the one promoting the best results in terms of $A$. blazei biological efficiency $(6.73 \%)$ and yield $(79.71 \%)$ was composed of $20 \%$ inoculum, $10 \%$ rice bran, without ammonium sulphate, using subsoil as casing material. Experiments that used $10 \%$ of urea as nitrogen source $(21,22,23,24,29,30,31$ and 32) showed no growth of $A$. blazei ( $\mathrm{BE}=0$ and $\mathrm{Y}=0$ ) indicating inhibition by high concentrations of urea. Experiments in which rice bran and subsoil were used showed, in general, higher values of $\mathrm{BE}$ and $\mathrm{Y}$, but the choice of the best condition was only possible based on statistical analysis. The statistical treatment of the values obtained for BE and $\mathrm{Y}$ with the different substrate formulations enabled the evaluation of the individual effects of the studied variables over these parameters, as well as the interactive effects between the factors. The results (Table 3) showed that the source of organic nitrogen promoted the highest effect over the yield and biological efficiency. In this case, the use of rice bran instead of urea led to better results. The concentration of the organic nitrogen (rice bran) at lower level (10\%) also promoted an increase of $\mathrm{BE}$ and $\mathrm{Y}$. According to Eira (2003), the substrates used for growing A. blazei showed $\mathrm{C}$ : $\mathrm{N}$ ratios varying from $30: 1$ to $37: 1$. Aiming to provide the culture of A. blazei with the right levels of nitrogen and carbon, the spent substrate of Pleurotus was supplemented with rice bran.

Table 3 - Estimated effects of evaluated factors on the biological efficiency (BE\%) and yield (Y\%) of Agaricus blazei.

\begin{tabular}{|c|c|c|}
\hline & \multicolumn{2}{|c|}{ Estimated effects } \\
\hline & BE \% & Y \% \\
\hline 1. Inoculum rate & $-0.01 \pm 0.21$ & $-0.53 \pm 1.64$ \\
\hline 2. Ammonium sulphate & $-0.22 \pm 0.21$ & $-3.65^{\mathrm{a}} \pm 1.64$ \\
\hline 3. Organic nitrogen concentration & $-1.35^{\mathrm{a}} \pm 0.21$ & $-13.73^{\mathrm{a}} \pm 1.64$ \\
\hline 4. Casing material & $0.96^{\mathrm{a}} \pm 0.21$ & $9.78^{\mathrm{a}} \pm 1.64$ \\
\hline 5. Source of organic nitrogen & $-3.75^{\mathrm{a}} \pm 0.21$ & $-33.29^{\mathrm{a}} \pm 1.64$ \\
\hline 1 by 2 & $-1.05^{\mathrm{a}} \pm 0.21$ & $-11.25^{\mathrm{a}} \pm 1.64$ \\
\hline 1 by 3 & $0.24 \pm 0.21$ & $-1.74 \pm 1.64$ \\
\hline 1 by 4 & $0.06 \pm 0.21$ & $0.49 \pm 1.64$ \\
\hline 1 by 5 & $-0.44^{\mathrm{a}} \pm 0.21$ & $-3.00 \pm 1.64$ \\
\hline 2 by 3 & $0.64^{\mathrm{a}} \pm 0.21$ & $9.15^{\mathrm{a}} \pm 1.64$ \\
\hline 2 by 4 & $-0.33 \pm 0.21$ & $-2.66 \pm 1.64$ \\
\hline 2 by 5 & $-0.07 \pm 0.21$ & $-1.97 \pm 1.64$ \\
\hline 3 by 4 & $0.11 \pm 0.21$ & $3.44^{\mathrm{a}} \pm 1.64$ \\
\hline 3 by 5 & $-0.40 \pm 0.21$ & $-1.23 \pm 1.64$ \\
\hline 4 by 5 & $-0.68^{\mathrm{a}} \pm 0.21$ & $-7.38^{\mathrm{a}} \pm 1.64$ \\
\hline $1 \times 2 \times 3$ & $-0.43^{\mathrm{a}} \pm 0.21$ & $-0.18 \pm 1.64$ \\
\hline $1 \times 2 \times 4$ & $0.29 \pm 0.21$ & $-2.54 \pm 1.64$ \\
\hline $1 \times 2 \times 5$ & $0.78^{\mathrm{a}} \pm 0.21$ & $8.82^{\mathrm{a}} \pm 1.64$ \\
\hline $1 \times 3 \times 4$ & $-0.72^{\mathrm{a}} \pm 0.21$ & $-8.34^{\mathrm{a}} \pm 1.64$ \\
\hline $1 \times 3 \times 5$ & $0.21 \pm 0.21$ & $5.27^{\mathrm{a}} \pm 1.64$ \\
\hline $1 \times 4 \times 5$ & $0.28 \pm 0.21$ & $3.03 \pm 1.64$ \\
\hline $2 \times 3 \times 4$ & $-0.27 \pm 0.21$ & $0.66 \pm 1.64$ \\
\hline $2 \times 3 \times 5$ & $-0.35 \pm 0.21$ & $-3.53^{\mathrm{a}} \pm 1.64$ \\
\hline $2 \times 4 \times 5$ & $0.42 \pm 0.21$ & $1.94 \pm 1.64$ \\
\hline $3 \times 4 \times 5$ & $-0.39 \pm 0.21$ & $-5.83^{\mathrm{a}} \pm 1.64$ \\
\hline${ }^{\mathrm{a}}$ Statistically significant values & & \\
\hline
\end{tabular}


Analysis of rice bran carried out by Dias et al. (1994) showed $13.30 \mathrm{~g} \%$ protein, 7.0 to $11.4 \mathrm{~g} \%$ fibre and 34.0 to $62.0 \mathrm{~g} \%$ carbohydrates. Thus, rice bran represents a good nitrogen source and an easily metabolized carbon source for this fungus. An inhibitory effect over the growth of A. blazei was observed when the concentration of urea was maintained in the higher level. According to Eira (2003), substrates with high initial nitrogen content and low metabolizable carbon content, have a higher lost of ammonia by volatilisation. Consequently, the content of nitrogen incorporated in the fungi biomass is lower.

Table 3 also shows that, although the isolated effect of the inoculum rate over BE and $\mathrm{Y}$ was not statistically significant, when the interaction effects over the factors were evaluated, better results were always found when $20 \%$ inoculum was used.

The interaction effect between the ammonium sulphate and the other factors was also statistically significant. In this case, the absence of this salt promoted better results for $\mathrm{BE}$ and $\mathrm{Y}$.

The casing material is an important factor. The choice of burned rice husk as one of the evaluated factors was induced by its physical-chemical characteristics. This material, which has been used with great success in the vegetative propagation of plants, has $150 \mathrm{~g} / \mathrm{l}$ dry density, $53.9 \%$ water retention capacity, $\mathrm{pH}$ of 7.4 in water and is light and porous, allowing good aeration and draining, as well as being free of noxious plants, nematodes and pathogens. Furthermore, this material does not need chemical treatment for sterilization, as it is carbonized (Souza 1993). Although these properties supported the desirable characteristics for a good casing material, visual analysis, after a period of daily irrigations, showed that it became a compact mass that would probably hinder the substrate aeration. This explained the low values of $\mathrm{BE}$ and $\mathrm{Y}$ obtained with burned rice husk when compared to those obtained with subsoil, traditionally used by mushroom producers.

The results of the statistical treatment showed that the best condition was that composed of $20 \%$ inoculum, $10 \%$ rice bran, without ammonium sulphate and covered with subsoil. This substrate formulation enabled a biological efficiency of $6.73 \% \pm 0.17$ and a yield of $79.71 \% \pm 2.07$. Eira (2003) reported a lower yield of A. blazei
(32.36\%) using sugar cane bagasse as substrate. However, Iwade and Mizuno (1997) using rice straw, organic fertilizers and rice bran showed results close to $15 \mathrm{~kg}$ fresh mushrooms $/ \mathrm{m}^{2}$ substrate. The results showed that the cultivation of A. blazei on Pleurotus spp spent substrate was technically viable opening a new opportunity for the mushroom producers, by enabling serial cultivation of two kinds of mushrooms, Pleurotus spp. and A. blazei with high added value.

The possibility of using a residue from the agro industry (banana tree leaves) for the cultivation of Pleurotus and to reuse the spent substrate for $A$. blazei culture adds value to the generated residue in the process, contributing to the development of agro business sustainability.

\section{ACKNOWLEDGMENTS}

The authors wish to thank the Federal Research Council of Brazil (CNPq), the Foundation of Research of Santa Catarina (FAPESC) and the University of the Region of Joinville UNIVILLE, for their financial support.

\section{RESUMO}

$\mathrm{O}$ cultivo de fungos comestíveis e medicinais utilizando resíduos da agroindústria vem se apresentando como uma alternativa econômica para o pequeno produtor rural, favorecendo a agricultura familiar do nordeste catarinense. Este trabalho avaliou o fungo Pleurotus para a decomposição lignocelulolítica de palha de folhas de bananeira e a utilização da palha residual como substrato para o cultivo de Agaricus blazei. Ajustes na composição do substrato residual de Pleurotus, tais como o tipo e a concentração da fonte de nitrogênio, a porcentagem de inóculo e a camada de cobertura, foram avaliadas. $\mathrm{O}$ substrato residual que mais favoreceu a produção de $A$. blazei em Eficiência Biológica (6,73\%), Rendimento $(79,71 \%)$ e menor tempo para emissão do primeiro primórdio (27 dias) foi o substrato residual de $P$. ostreatus inoculado com $20 \%$ de inóculo (ms), $10 \%$ de farelo de arroz (ms), sem sulfato de amônio e utilizando terra de subsolo como camada de cobertura. 


\section{REFERENCES}

Bonatti, M., Karnopp, P., Soares, H.M., Furlan, S.A. (2004), Evaluation of Pleurotus ostreatus and Pleurotus sajor-caju nutritional characteristics when cultivated in different lignocellulosic wastes. Food Chem., 88 (3), 425-428

Chang, R. (1996), Functional properties of edible mushrooms. Nutr. Rev., 54(11), 91-93

Dias, L.C.G.D, Reyes, F., Camargo, J.L.V., Rodrigues, M.A.M. (1994), Conteúdos de celulose, hemicelulose e lignina no farelo de arroz fresco. Rev. Nutr. - PucCampinas, 7, 62-71

Nascimento, J. S. and Eira, A. F. (2007), Isolation and mycelial growth of Diehliomyces microsporus: effect of culture medium and incubation temperature. Braz. Arch. Biol. Technol., 50 (4), 587-595

Eira, A. (2003), Cultivo do cogumelo medicinal Agaricus blazei. Aprenda Fácil, Viçosa

Gunde-Cimerman, N. (1999), Medicinal value of the genus Pleurotus (Fr.) P. Karst. (Agaricales s.I., Basidiomycetes). Int. J. Med.Mushrooms, 1, 69-80

Hernández, D., Sánchez, J., Yamasaki, K. (2003), A simple procedure for preparing substrate for Pleurotus ostreatus cultivation. Bioresour. Technol., 90, $145-150$

Iwade, I. and Mizuno, T. (1997), Cultivation of Kawariharatake (Agaricus blazei Murill). Food Rev. Int., 13(3), 383-390

Kanotra, S. and Mathur, R.S. (1994), Biodegradation of paddy straw with cellulolytic fungi and its application on wheat crop. Bioresour. Technol., 47, $185-188$

Obodai, M., Cleland-Okine, J., Vowotor, K.A. (2003), Comparative study on the growth and yield of Pleurotus ostreatus mushroom on different lignocellulosic by-products. J. Ind. Microbiol. Biotechnol., 30 (3), 146-149

Oei, Peter. (1996), Mushroom Cultivation (for developing countries). Tool Publications, Leiden, pp.143-160
Patrabansh, S. and Madan, M. (1997), Studies on cultivation, biological efficiency and chemical analyses of Pleurotus sajor-caju (Fr.) Singer on different bio-wastes. Acta Biotechnol., 17 (2), 107 122

Rorabacher, D. B. (1991), Statistical treatment for rejection of deviant values: critical values of Dioxon's "Q" parameter and related subrange ratios at the $95 \%$ confidence level. Anal. Chem., 63 (2), $139-146$

Royse, D.J. (1992), Recycling of spent shiitake substrate for production of oyster mushroom, Pleurotus sajor-caju. Appl. Microbiol. Biotechnol., 38, 179-182

Salmones, D., Mata, G., Waliszewski, K.N. (2005), Comparative culturing of Pleurotus spp. on coffee pulp and wheat straw: biomass production and substrate biodegradation. Bioresour. Technol., 96 (5), 537-544

Silva, S.O., Gomes da Costa, S.M., Clemente, E. (2002), Chemical composition of Pleurotus pulmonarius (Fr.) Quél., substrates and residue after cultivation. Braz. Arch. Biol. Technol., 45(4), 531535

Silveira, M. L. L., Wisbeck, E., Ninow, J. L., Gern, R. M. M., Furlan, S. A. (2006), Pleurotus cultivation in submerged culture and nutritional value of fruit bodies cultivated in solid culture. In - Currents Topics on Bioprocesses in Food Industry, eds. C. Larroche, A. Pandey, C. G. Dussap. Asiatech Publishers, New Delhi, pp. 197-203

Souza, F. X. (1993), Casca de arroz carbonizada: um substrato para a propagação de plantas. Rev. Lavoura Arrozeira, 46 (406), 11

Zadrazil, F. and Puniya, A.K. (1995), Studies on the effect of particle size on solid-state fermentation of sugarcane bagasse into animal feed using white-rot fungi. Bioresour. Technol., 54, 85-87

Received: June 16, 2008; Revised: October 02, 2008; Accepted: October 21, 2009. 